\title{
MATHEMATICS LITERACY MOBILE LEARNING APPLICATION: Pengembangan Bahan Ajar Literasi Matematika Berbasis Android
}

\author{
Fatimatul Khikmiyah ${ }^{1}$, Putri Aisyiyah Rakhma D ${ }^{2}$ \\ Universitas Muhammadiyah Gresik ${ }^{1,2}$ \\ fatim@umg.ac.id \\ Universitas Muhammadiyah Gresik ${ }^{1,2}$ \\ putriaisyiyah@gmail.com
}

\begin{abstract}
Abstrak
Dalam pembelajaran matematika, teknologi merupakan hal yang pokok karena teknologi mempengaruhi bagaimana matematika itu akan diajarkan dan sangat bermanfaat dalam memfasilitasi peserta didik dalam belajar. NCTM (2002) "Technology is essential part in teaching and learning mathematics; it influences the Mathematics that is taught and enhances students' learning". Literasi merupakan salah satu unsur yang dinilai dalam Programme for International Student Assessment (PISA) yang meliputi literasi matematika, literasi sains, literasi keuangan, literasi bahasa. Data terbaru PISA masih belum menggembirakan. Siswa Indonesia hanya mampu menjawab soal dalam kategori rendah dan sedikit sekali yang dapat menjawab soal yang menuntut pemikiran tingkat tinggi. Dalam penelitian ini digunakan penelitian pengembangan model Hannafin \& Peck meliputi tiga fase, yaitu yaitu analisis kebutuhan (Need Assessment), fase desain (Design), serta fase pengembangan dan implementasi (Develop and Implement). Pada tahap analisis kebutuhan dilakukan analisis terhadap kurikulum yang berlaku di sekolah, mengidentifikasi karakteristik peserta didik dan analisis materi. Peserta didik usia SMP sangat akrab dengan telepon genggam (Handphone) meskipun mereka dilarang membawanya ke sekolah. Dengan adanya buku ajar dalam bentuk aplikasi berbasis android maka peserta didik memiliki kesempatan yang luas untuk belajar matematika tanpa batas ruang dan waktu. Gaya belajar peserta didik yang dominan adalah gaya belajar visual. Peserta didik dengan gaya belajar ini menyukai belajar dengan tulisan, tabel, gambar dan bentuk lain dalam visualisasi. Oleh karena itu, dalam pengembangannya bahan ajar literasi matematika akan memadukan tulisan dan gambar dengan animasi sehingga mengakomodir kebutuhan peserta didik. Hasil analisis yang diperoleh pada fase sebelumnya kemudian diterjemahkan dalam bentuk story board. Dokumen story board dalam penelitian ini terdiri atas diagram alur aplikasi, rancangan tampilan, kisi-kisi tes formatif, dan instrumen tes formatif. Pada tahap pengembangan dihasilkan Aplikasi buku ajar literasi matematika berbasis adnroid yang disebut Draft 1. Berdasarkan hasil analisis penilaian ahli dan uji coba terbatas, pengembangan bahan ajar literasi matematika berbasis Android ini memenuhi kategori praktis dan efektif.
\end{abstract}

Kata Kunci :Bahan Ajar, Literasi matematika, Android

\begin{abstract}
In mathematics learning, technology is the main thing because technology influences how mathematics will be taught and is very useful in helping students learn. NCTM (2002) "Technology is essential in teaching and learning mathematics; it influences the Mathematics that is taught and enhances students' learning. Literacy is one of the elements assessed in the Program for International Student Assessment (PISA) which includes mathematical literacy, scientific literacy, financial literacy, language literacy. The latest PISA data is still not encouraging. Indonesian students are only able to answer questions in low categories and very few can answer questions that require high level thinking. In this study, Hannafin \& Peck's model development research used three phases, namely the needs analysis, the design phase, and the development and implementation phases (Develop and Implement). At the stage of the needs analysis an analysis of the curriculum that applies in the school is carried out, identifying the characteristics of students and material analysis. Middle school students are very familiar with mobile phones (Mobile) even though they are prohibited from taking them to school. With the existence of textbooks in the form of android-based applications, students have a wide opportunity to learn mathematics without limits of space and time. The dominant learning style of
\end{abstract}


students is the visual learning style. Students with this learning style love learning with writing, tables, images and other forms of visualization. Therefore, in the development of mathematics literacy teaching materials will combine writing and images with animation to accommodate the needs of students. The results of the analysis obtained in the previous phase are then translated in the form of a story board. The story board document in this study consisted of application flow diagrams, display design, formative test grids, and formative test instruments. At the development stage, an androidbased mathematics literacy textbook application called Draft 1. Based on the results of expert assessment analysis and limited trials, the development of this Android-based mathematics literacy teaching material meets practical and effective categories.

Kata Kunci : Teaching materials, Mathematics Literacy, Android

\section{PENDAHULUAN}

Teknologi Mobile beserta aplikasinya saat ini menjadi bagian yang tidak terpisahkan dari kehidupan guru dan peserta didik di seluruh belahan dunia. Teknologi ini telah mengubah gaya hidup, cara orang berkomunikasi, mencari informasi dan belajar. Dalam pembelajaran, teknologi ini melahirkan sebuah konsep baru yaitu Mobile Learning yang biasa disingkat dengan M-Learning.

Oleh karena itu, tantangan guru dan peneliti di masa kini dan masa yang akan datang adalah bagaimana menggunakan teknologi secara efektif dalam meningkatkan kompetensi dan keterampilan peserta didik.

NCTM (2002) “Technology is essential in mathematics learning; it influences the how mathematics is taught and enhances students' learning”. Artinya, teknologi merupakan hal yang penting dalam pembelajaran matematika karena dapat ,mempengaruhi cara mengajarkan matematika dan sangat bermanfaat bagi proses belajar peserta didik. Drigas, A.S (2015) memaparkan beberapa aplikasi inovatif yang dikembangkan di seluruh dunia sejak tahun 2003 hingga 2013 untuk pembelajaran matematika dari tingkat anak usia dini sampai dengan perguruan tinggi. Dalam kesimpulannya dijelaskan bahwa pembelajaran matematika secara online maupun menggunakan aplikasi dapat meningkatkan kemampuan bilangan dan aritmatika, representasi matematika, konstruksi objek geometri, penyelesaian masalah aljabar dan pemrograman matematika.

Lebih lanjut Drigas, A.S (2015) memaparkan bahwa pembelajaran matematika secara online maupun dengan aplikasi dapat memotivasi peserta didik, membuat suasana pembelajaran lebih menyenangkan dan interaktif jika dibandingkan dengan pembelajaran biasa. Dengan adanya M-Learning maka pembelajaran dapat dilakukan kapan saja dan dimana saja, menyediakan akses belajar tanpa batas bahkan di luar sekolah 
(Motiwalla, 2007). Pembelajaran seperti ini tentu saja memungkinkan peserta didik untuk memanfaatkan waktu-waktu luangnya di luar kelas untuk meningkatkan kemampuan dan pengetahuannya. Sementara itu, studi kasus yang dilakukan oleh Botzer dkk (2007) menunjukkan bahwa pembelajaran dengan menggunakan aplikasi matematika mampu meningkatkan kemampuan operasi matematika sekaligus meningkatkan pengalaman belajar peserta didik.

Literasi merupakan salah satu unsur yang dinilai dalam Programme for International Student Assessment( PISA). Literasi dalam PISA meliputi literasi matematika, literasi sains, literasi keuangan, literasi bahasa. Data terbaru Programme for International Student Assessment (PISA) masih belum menggembirakan. Pada tahun 2015, ratarata skor matematika peserta didik Indonesia 386 di bawah rata-rata OECD 490. Persentase peserta didik yang berada di level 5 atau 6 sebesar $0,8 \%$ dan peserta didik yang berada di bawah level 2 sebanyak 42,3\%(OECD, 2015: 5). Hasil tersebut masih menunjukkan bahwa siswa Indonesia hanya mampu menjawab soal dalam kategori rendah dan sedikit sekali yang dapat menjawab soal yang menuntut pemikiran tingkat tinggi.

Literasi matematika melibatkan 7 kemampuan dasar yang harus dimiliki
(OECD, 2010: 18-19), yaitu:

Communication, kemampuan untuk mengomunikasikan masalah;

Mathematising, kemampuan untuk mengubah permasalahan dari dunia nyata ke bentuk matematika ataupun sebaliknya; (3) Representation, kemampuan untuk menyajikan kembali suatu permasalahan matematika; (4) Reasoning and Argument, kemampuan menalar dan memberi alasan; (5) Devising Strategies for Solving Problems, kemampuan menggunakan strategi memecahkan masalah; (6) Using Symbolic, Formal and Technical Language and Operation, kemampuan menggunaan bahasa simbol, bahasa formal dan bahasa teknis; (7)Using Mathematics Tools, kemampuan menggunakan alat-alat matematika, misalnya dalam pengukuran.

Untuk mengembangkan kemampuan literasi matematika peserta didik, maka dibutuhkan berbagai upaya yang komprehensif dari berbagai pihak. Salah satu upaya dilakukan oleh Khikmiyah (2016) yang telah mengembangkan buku ajar literasi matematika untuk pembelajaran di SMP yang didanai oleh DIKTI dalam skema Penelitian Dosen Pemula(PDP). Proses diseminasi buku ajar yang telah dikembangkan terhambat oleh biaya cetak yang relatif mahal dan kondisi geografis yang tidak memungkinkan. Untuk mendapatkan buku pengayaan seperti ini, tentu saja guru dan peserta 
didik harus mengeluarkan biaya tambahan. Beberapa alumni Prodi Pendidikan Matematika Universitas Muhammadiyah Gresik yang berada di daerah 3T mengalami kesulitan untuk mendapatkan buku ini karena tidak ada anggaran khusus dari sekolah maupun dari orang tua peserta didik. Di samping itu, Tes PISA pada tahun 2015 yang secara keseluruhan telah berbasis komputer(Computer Based Test) padahal model penilaian dengan komputer seperti ini baru saja diterapkan di negara Indonesia secara serentak pada ujian nasional tahun 2017 untuk level Sekolah Menengah Pertama. Oleh karena itu, untuk mengatasi hal ini maka peserta didik di Indonesia seyogyanya dilatih untuk melek teknologi dengan menggunakan teknologi dalam pembelajaran sesering mungkin. Hal yang ditawarkan oleh peneliti adalah mengembangkan buku ajar tersebut dalam bentuk software (aplikasi) pembelajaran matematika yang dalam penelitian ini disebut Mathematics Literacy Mobile Learning Application (ML2A).

Berdasarkan latar belakang yang telah dipaparkan pada bagian sebelumnya, maka tujuan penelitian ini adalah menghasilkan bahan ajar literasi matematika berbasis android: Mathematics Literacy Mobile Learning Application (ML2A) yang dapat digunakan oleh guru dan peserta didik sebagai materi tambahan dalam implementasi kurikulum 2013 sehingga dapat meningkatkan kemampuan literasi peserta didik usia 15 tahun atau pada jenjang Sekolah Menengah Pertama (SMP).

\section{METODE PENELITIAN}

Model penelitian ini adalah penelitian pengembangan atau Research and Development (R\&D) yang mengacu pada model Hannafin\&Peck. Model pengembangan ini meliputi tiga fase, yaitu yaitu analisis kebutuhan (Need Assessment), fase desain (Design), serta fase pengembangan dan implementasi (Develop and Implement). Model pengembangan tersebut dapat digambarkan sebagai berikut:

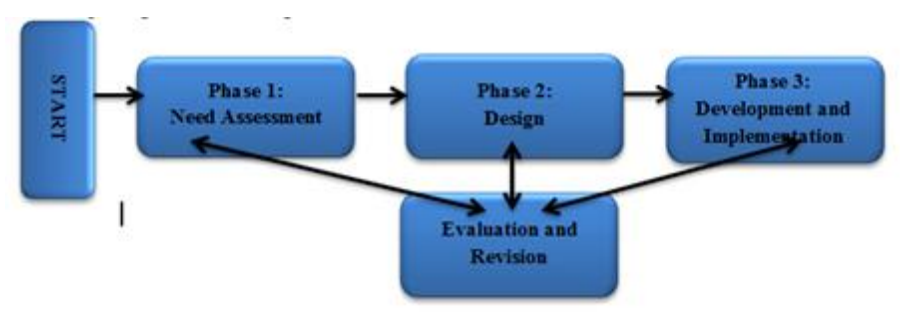

Gambar 1. Model Pengembangan Hannafin\&Peck

Pada kegiatan analisis dilakukan analisis kurikulum, analisis peserta didik dan analisis materi.Pada fase desain, informasi dari fase analisis kebutuhan diterjemahkan dalam bentuk story board yang diurutkan berdasarkan keperluan dalam pembelajaran. Setelah story board dibuat, langkah selanjutnya adalah mengevaluasi dan merevisi hasil desain 
sebelum melanjutkan ke fase pengembangan dan uji coba terbatas.

Berdasarkan tahapan penelitian yang disajikan pada bagian sebelumnya, maka rancangan penelitian pengembangan ini dapat digambarkan sebagai berikut:

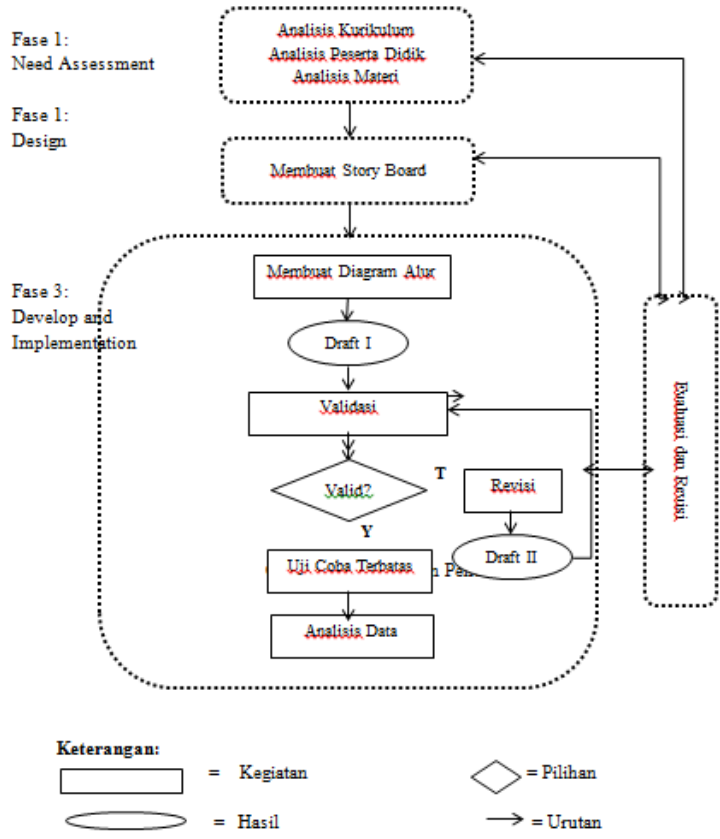

Gambar 2. Rancangan Penelitian

Metode pengumpulan data meliputi metode validasi, metode angket dan metode tes. Sedangkan instrumen yang akan digunakan adalah kuisioner dan tes. Bahan ajar dikembangkan dikatakan valid jika rata-rata nilai validator berada dalam kategori valid atau cukup valid dengan rentang sebagai berikut:

$3 \leq R T V \leq 4$ : valid

$2 \leq R T V<3$ : cukup valid

$1 \leq R T V<2$ : tidak valid
$R T V=$ Nilai rata-rata dari dua validator

Selanjutnya bahan ajar dikatakan praktis jika validator menyatakan bahwa aplikasi tersebut dapat digunakan dengan sedikit atau tanpa revisi. Uji Coba terbatas akan dilaksanakan di SMP Muhammadiyah 1 Gresik.

\section{HASIL DAN PEMBAHASAN}

Penelitian ini bertujuan untuk mendeskripsikan proses pengembangan bahan ajar literasi matematika yang berbasis Android yang ditujukan bagi peserta didik usia 15 tahun atau pada jenjang Sekolah Menengah Pertama (SMP). Proses dan hasil pengembangan bahan ajar tersebut dipaparkan dalam uraian di bawah ini:

Hasil analisis yang diperoleh pada fase sebelumnya kemudian diterjemahkan dalam bentuk story board. Storyboard ini diurutkan berdasarkan kebutuhan guru dan peserta didik dalam proses pembelajaran. Dokumen story board dalam penelitian ini terdiri dari diagram alur aplikasi, rancangan tampilan, kisi-kisi tes formatif, dan instrumen tes formatif.

Format tampilan yang dipilih yaitu 1) tampilan cover berisi judul aplikasi dan identitas penulis, 2) setiap halaman memilik background yang dibuat oleh peneliti dan dikomposisikan dengan tulisan 
yang diberi warna sedemikian hingga mudah untuk dibaca, 3) Halaman yang berisi materi dan tulisan lain menggunakan jenis font Times New Roman dan ukuran font berkisar dari 15-35, 4) halaman yang dapat dibuka melalui menu dilengkapi dengan tombol navigasi seperti kembali, menu dan lanjut, 5) Bagian tes formatif dilengkapi dengan feedback yang berisi nilai yang diperoleh peserta didik setelah menjawab pertanyaan-pertanyaan yang tersedia.

Desain awal dari Mathematics Literacy Mobile Learning Application (ML2A) disebut sebagai draft I. ML2A terdiri dari beberapa menu utama, yaitu (1) petunjuk penggunaan, (2) Tahapan pemecahan masalah matematika, (3) Bagian Isi yang terdiri dari 7(tujuh ) bab, dimana setiap bab terdiri dari ilustrasi, paparan materi, tugas diskusi kelompok dan tes formatif.

\section{Deskripsi tahap analisis Kebutuhan}

(Need Assessment)

Analisis kebutuhan dimaksudkan untuk mengidentifikasi hal-hal apa saja yang dibutuhkan dalam mengatasi masalah yang akan ditemuai dalam kegiatan pembelajaran. Pada tahap ini dilakukan analisis terhadap kurikulum yang berlaku di sekolah, mengidentifikasi karakteristik peserta didik dan analisis materi. Adapun hasil dari dari setiap tahap analisis di paparkan seperti di bawah ini:

\section{A. Analisis kurikulum}

Analisis kurikulum dilakukan dengan analisis dokumen yatiu silabus, RPP, dan bahan ajar yang digunakan oleh guru dan peserta didik. Selain itu juga dilakukan wawancara dengan guru dan peserta didik di SMP Muhammadiyah 1 Gresik. Berdasarkan dokumen perangkat pembelajaran dan penjelasan guru diketahui bahwa peserta didik kelas VII sampai kelas IX telah menggunakan kurikulum 2013. Referensi yang digunakan oleh guru dan peserta didik adalah buku kurikulum 2013 revisi 2017. Sementara itu, dengan diterpkannya 5(lima) hari belajar di sekolah, maka peserta didik membutuhkan sumber belajar lain yang mudah diakses oleh mereka. Peserta didik usia SMP sangat akrab dengan telepon genggam (Handphone) sehingga dengan adanya buku ajar dalam bentuk aplikasi berbasis android maka peserta didik memiliki kesempatan yang luas untuk belajar tampa batas ruang dan waktu.

B. Analisis peserta didik

Sebagaimana dijelaskan sebelumnya bahwa target audience pada penelitian ini adalah peserta didik usia 15 tahun sehingga analisis peserta didik dilakukan terhadap peserta didik kelas IX. Adapun Subjek dalam penelitian ini adalah peserta didik di SMP Muhammadiyah 1 Gresik. Peserta didik kelas IX yang berusia antara 14-15 tahun menurut teori kognitif Piaget berada 
pada tahap Operasional formal, artinya peserta didik sudah dapat berhubungan dengan peristiwa-peristiwa hipotesis atau abstrak. Sehingga konteks permasalahan yang diberikan bisa sangat bervariasi sesuai dengan konteks yang digunakan dalam PISA yaitu konteks pribadi, konteks sosial, konteks pendidikan/pekerjaan dan konteks pengetahuan. Selain itu, peserta didik harus sering dilatih memecahkan masalah melalui pengujian alternatif yang ada sehingga kemampuannya dapat berkembang dengan baik.

Untuk memperoleh data tentang gaya belajar peserta didik, maka dilakukan penyebaran angket kepada siswa kelas IX yaitu kelas IX A, IX C dan IX D yang berjumlah 84 peserta didik. Dari hasil analisis angket peserta didik diperoleh data gaya belajar peserta didik sebagai berikut:

Tabel 1. Analisis gaya belajar peserta didik

\begin{tabular}{|c|c|c|c|}
\hline $\begin{array}{l}\mathbf{N} \\
\mathbf{O}\end{array}$ & $\begin{array}{c}\text { GAYA } \\
\text { BELAJAR }\end{array}$ & $\begin{array}{c}\text { BANYAK } \\
\text { NYA } \\
\text { SISWA }\end{array}$ & $\begin{array}{c}\text { PERSENTA } \\
\text { SE }\end{array}$ \\
\hline 1 & Visual & 41 & $49 \%$ \\
\hline 2 & Auditori & 25 & $30 \%$ \\
\hline \multirow[t]{2}{*}{3} & Kinestetik & 18 & $21 \%$ \\
\hline & JUMLAH & 84 & $100 \%$ \\
\hline
\end{tabular}

\section{Deskripsi Tahap Pengembangan} dan Implementasi (Develop and

\section{Implement)}

Pada tahap pengembangan dilakukan 2(dua) kegiatan yaitu pengembangan dan Impelementasi
A. Pengembangan

Dokumen story board yang dihasilkan pada fase desain diwujudkan dalam fase ini. Pada tahap ML2A yang dihasilkan disebut dengan Draft I. Tahapan pembuatan aplikasi Draft I adalah sebagai berikut:

(1) Mempersiapkan desain tampilan setiap halaman dalam aplikasi Draft I. dalam mempersiapkan desain tampilan tersebut termasuk didalamnya mempersiapkan segala tulisan dan gambar yang akan ditampilkan di dalam aplikasi Draft I. Desain tampilan mengacu pada rancangan tampilan dalam dokumen story board.

(2) Membuat ML2A pada Adobe Flash Profesional C6. Langkah awal yang dilakukan adalah membuat frame-frame baru. Jumlah frame yang dibuat adalah 145 frame. Selanjutnya memindahkan semua file gambar dan materi dalam setiap frame ke dalam aplikasi ML2A

(3) Mengecek jalannya aplikasi.

(4) Mempersiapkan aplikasi berformat swf. Mempersiapkan aplikasi berformat swf. Aplikasi yang telah dibuat dan siap untuk digunakan secara 
langsung di perangkat mobile dikemas terlebih dahulu agar menjadi file berformat swf. File swf dapat dibuat dengan menggunakan menu "File" kemudian pilih Publish Setting - Swf - Publish. Mathematics Mobile Learning Application dengan materi Pola Bilangan yang telah menjadi format $s w f$ dapat dijalankan di seluruh perangkat mobile berbasis android dengan menginstal aplikasi Flash Player New.

\section{B. Implementasi}

Yang dimaksud tahap implementasi dalam penelitian ini adalah penilaian formatif dan penilaian sumatif. Setelah dihasilkan draft I, selanjutnya dievaluasi oleh validator (penilaian formatif) untuk selanjutnya dilakukan perbaikan. Evaluasi ahli desain meliputi tema desain, tampilan media, serta komposisi isi dan warna sedangkan evaluasi ahli materi meliputi keluasan, kedalaman dan kesesuaian konten terhadap peserta didik. Jika draft I dinyatakan valid maka draft I inilah yang akan digunakan dalam uji coba terbatas, jika tidak maka draft II sebagai perbaikan dari draft I yang akan digunakan dalam uji coba terbatas. Akan tetapi, jika draft II berdasarkan penilaian validator belum memenuhi kriteria valid maka draft tersebut akan dilakukan perbaikan kembali sampai didapatkan hasil yang memenuhi kriteria valid dan layak diujikan secara terbatas.

Penilaian ini dilakukan oleh 4(empat) validator yaitu 2(dua) ahli materi dan 2(dua) ahli desain. Ahli materi dalam penelitian ini adalah Nur Fauziyah, M. Pd dan Syaiful Huda, M. Si sedangkan ahli desain yaitu Iqnatia Alfiansyah, M. Pd dan Arya Setya Nugroho, M. Pd. Hasil dari validasi digunakan untuk menyempurnakan aplikasi ML2A agar mencapai kualitas maksimal. Tabel berikut menjelaskan nilai validasi oleh masing-masing ahli.

Tabel 2. Hasil Analisis Validasi ahli materi dan ahli media

\begin{tabular}{|l|c|c|}
\hline AHLI & $\begin{array}{c}\text { Rata- } \\
\text { rata } \\
\text { Nilai }\end{array}$ & Komentar \\
\hline $\begin{array}{l}\text { Ahli } \\
\text { Materi 1 }\end{array}$ & 3,5 & $\begin{array}{c}\text { Dapat digunakan } \\
\text { dengan sedikit } \\
\text { revisi }\end{array}$ \\
\hline $\begin{array}{l}\text { Ahli } \\
\text { Materi 2 }\end{array}$ & 3,5 & $\begin{array}{c}\text { Dapat digunakan } \\
\text { dengan sedikit } \\
\text { revisi }\end{array}$ \\
\hline $\begin{array}{l}\text { Ahli } \\
\text { Media 1 }\end{array}$ & 3,6 & $\begin{array}{c}\text { Dapat digunakan } \\
\text { tanpa revisi }\end{array}$ \\
\hline $\begin{array}{l}\text { Ahli } \\
\text { Media 2 }\end{array}$ & 3,4 & $\begin{array}{c}\text { Dapat digunakan } \\
\text { dengan sedikit } \\
\text { revisi }\end{array}$ \\
\hline Rata-rata & 3,5 & \\
\hline
\end{tabular}


Tabel di atas menunjukkan bahwa seluruh nilai hasil validasi para ahli berada pada rentang $3 \leq R T V \leq$ 4, begitu juga dengan nilai rata-rata yang diperoleh yaitu sebesar 3,5 yang berada pada kategori valid. Selanjutnya 3(tiga) dari 4(empat) ahli memberi komentar bahwa buku ajar yang telah dikembangkan dapat digunakan dengan sedikit revisi. Berikut adalah saran yang diberikan oleh para ahli dan upaya tindak lanjut yang dilakukan oleh peneliti

Tabel 3. Saran dari ahli materi dan ahli media serta upaya tindak lanjut

peneliti

\begin{tabular}{|l|l|l|}
\hline $\begin{array}{c}\text { VALIDAT } \\
\text { OR }\end{array}$ & SARAN & $\begin{array}{c}\text { UPAYA } \\
\text { TINDAK } \\
\text { LANJUT }\end{array}$ \\
\hline Ahli Materi & $\begin{array}{l}\text { Bahasa } \\
\text { sebaiknya } \\
\text { dibuat } \\
\text { menjadi } \\
\text { lebih } \\
\text { sederhana } \\
\text { disajikan } \\
\text { dengan } \\
\text { bahasa yang } \\
\text { lebih } \\
\text { sederhana } \\
\text { sesuai } \\
\text { karakter } \\
\text { peserta didik }\end{array}$ \\
\hline & $\begin{array}{l}\text { Soal yang } \\
\text { berkategor } \\
\text { i sulit } \\
\text { terlalu } \\
\text { banyak }\end{array}$ & $\begin{array}{l}\text { Mengurangi } \\
\text { jumlah soal } \\
\text { yang } \\
\text { berkategori } \\
\text { sulit }\end{array}$ \\
\hline \multirow{4}{*}{ Ahli Materi } & $\begin{array}{l}\text { Perbaiki } \\
\text { kesalahan } \\
\text { penulisan } \\
\text { di } \\
\text { berbagai } \\
\text { tempat }\end{array}$ & $\begin{array}{l}\text { Memperbaiki } \\
\text { kesalahan } \\
\text { penulisan }\end{array}$ \\
\hline & $\begin{array}{l}\text { Pengguna } \\
\text { an kata }\end{array}$ & $\begin{array}{l}\text { Kata-kata } \\
\text { yang dipilih }\end{array}$ \\
\hline
\end{tabular}

\begin{tabular}{|l|l|l|}
\hline & $\begin{array}{l}\text { atau } \\
\text { kalimat } \\
\text { disesuaika } \\
\text { n dengan } \\
\text { pembaca }\end{array}$ & $\begin{array}{l}\text { dan penataan } \\
\text { kalimatnya } \\
\text { disederhanak } \\
\text { an terutama } \\
\text { yang terdapat } \\
\text { pada bab I }\end{array}$ \\
\hline Ahli Media 2 & $\begin{array}{l}\text { Cover } \\
\text { kurang } \\
\text { menarik, } \\
\text { perlu } \\
\text { disertai } \\
\text { gambar }\end{array}$ & $\begin{array}{l}\text { Menambahka } \\
\text { ngambar } \\
\text { pada cover }\end{array}$ \\
\hline
\end{tabular}

Setelah media dinyatakan valid oleh para ahli dan dilakukan revisi, maka langkah berikutnya adalah melaksanakan uji coba terbatas. Uji coba ini dilaksanakan pada semester ganjil tahin pelajaran 2018/2019 di kelas IX A SMP Muhammadiyah 1 Gresik dengan jumlah peserta didik sebanyak 28. Sehubungan dengan adanya larangan penggunaan Handphone(HP) di sekolah, maka uji coba dilaksanakan dengan menggunakan komputer laboratorium. Uji coba terbatas dilaksanakan dengan pembelajaran sebanyak 2(dua) pertemuan, yaitu pada materi Statistika. Secara rinci, kompetensi dasar untuk pertemuan 1 dan 2 disajikan dalam tabel berikut:

Tabel 4. Pelaksanaan Uji coba terbatas dan KD yang dilaksanakan

\begin{tabular}{|c|l|}
\hline $\begin{array}{c}\text { PERTEMUAN } \\
\text { KE }\end{array}$ & KOMPETENSI DASAR \\
\hline 1 & $\begin{array}{l}\text { Menerapkan pola dan } \\
\text { generalisasi untuk } \\
\text { membuat prediksi. }\end{array}$ \\
\hline 2 & $\begin{array}{l}\text { Menentukan nilai rata- } \\
\text { rata, median, dan modus }\end{array}$ \\
\hline
\end{tabular}


dari berbagai jenis data.

Setelah melaksanakan pembelajaran dalam rangka uji coba terbatas, maka langkah selanjutnya adalah melaksanakan tes hasil belajar untuk mengukur apakahbuku ajar berbasis android yang telah dikembangkan memenuhi kategori efektif atau tidak. Tes hasil belajar dilaksanakan pada tanggal 29 November 2018 dengan hasil sebagai berikut:

Tabel 5. Analisis Tes Data Hasil Belajar

\begin{tabular}{|c|c|c|}
\hline KETERANGAN & JUMLAH & PERSEN \\
\hline $\begin{array}{c}\text { Peserta didik yang } \\
\text { tuntas }\end{array}$ & 20 & $71,43 \%$ \\
\hline $\begin{array}{c}\text { Peserta didik yang } \\
\text { tidak tuntas }\end{array}$ & 8 & $28,57 \%$ \\
\hline
\end{tabular}

Berdasarkan tabel tersebut maka dapat disimpulkan bahwa bahan ajar berbasis android yang telah dikembangkan telah memenuhi kategori efektif dengan tingkat ketuntasan sebesar 71,43\%.

\section{PEMBAHASAN}

Bahan Ajar Literasi Matematika Berbasis Android yang telah dikembangkan telah memenuhi kriteria valid dan praktis. Hal ini didasarkan pada penilaian ahli materi dan ahli media. Sedangkan hasil uji coba terbatas menunjukkan bahwa buku ini belem mencapai kategori efektif karena ketuntasan belajar klasikal belum mencapai $70 \%$ seperti yang ditetapkan oleh
SMP Muhammadiyah 1 Gresik. Meskipun demikian, penyajian tahapan penyelesaian masalah yang menggunakan tahapan Polya melatih peserta didik untuk berpikir secara sistematis, berpikir kritis dan menggunakan logika berpikirnya.

\section{Bahan Ajar Literasi Matematika} Berbasis Android yang telah dikembangkan telah memenuhi kategori efektif meskipun tingkat ketuntasan klasikalnya sedikit di atas ambang batas, hal ini dapat dimaklumi karena sebagian besar masalah yang disajikan memiliki tingkat koneksi matematis yang tinggi baik dengan konsep matematika yang lain atau dengan kehidupan sehari-hari. Buku berbasis android ini diharapkan dapat menjadi referensi tambahan bagi guru dan peserta didik di Sekolah menengah Pertama. Selain itu, penyajian buku melalui aplikasi ini diharapkan juga memenuhi kebutuhan belajar peserta didik yang tidak terbatasa pada tempat dan waktu.

\section{SIMPULAN \& SARAN}

\section{Simpulan}

Pengembangan bahan ajar literasi matematika berbasis android dilakukan dengan tahapan-tahapan sebagai berikut:

1. Analisis kebutuhan(Need Assessment) Pada tahap ini dilakukan analisis terhadap kurikulum yang berlaku di 
sekolah, mengidentifikasi karakteristik peserta didik dan analisis materi.

2. Tahap Perancangan(Design)

Hasil analisis yang diperoleh pada fase sebelumnya kemudian diterjemahkan dalam bentuk story board. Storyboard ini diurutkan berdasarkan kebutuhan guru dan peserta didik dalam proses pembelajaran. Dokumen story board dalam penelitian ini terdiri dari diagram alur aplikasi, rancangan tampilan, kisi-kisi tes formatif, dan instrumen tes formatif..

3. Tahap pengembangan dan Implementasi (Develop and Implement)

Dokumen story board yang dihasilkan pada fase desain diwujudkan dalam fase pengembangan ini. Setelah itu, dilakukan penilaian formatif dan penilaian sumatif. Penilaian formatif dilakukan oleh validator sedangkan penilaian sumatif dilakukan oleh peserta didik dengan mengerjakan soal latihan , mengisi angket dan melaksanakan tes hasil belajar.

Berdasarkan penilaian formatif dan sumatif dapat dinyatakan bahwa buku ajar literasi matematika berbasis Android yang telah dikembangkan memenuhi tingkat praktis minimal pada kategori baik.

\section{Saran}

Berdasarkan kesimpulan yang diperoleh,maka peneliti memberikan saran sebagai berikut:

1. Bahan ajar literasi matematika yang dikembangkan dapat digunakan oleh guru sebagai materi tambahan untuk meningkatkan kemampuan berpikir matematika tingkat tinggi peserta didik.

2. Peneliti selanjutnya dapat mengembangkan pada instrument penilaian yang digunakan dalam melihat kemampuan literasi matematis peserta didik.

\section{DAFTAR PUSTAKA}

Botzer, G \& Yerushalmy (2007). M. Mobile application for mobile learning. In Proceeding of The International Conference On Cognition and Exploratory Learning in Digital Age, pp. 7-9

Drigas, A.S \& Pappas M.A. (2015). A Review of Mobile Learning Applications for Mathematics. International Journal of Interactive Mobile Technologies Volume 9 No 3. Hal $18-23$

Georgiev, Tsvetozar, dkk. (2004). MLearning - a New Stage of ELearning. International Conference on Computer System and Technologies- CompSysTech'2004 
(http://ecet.ecs.ru.acad.bg/cst04/Docs /sIV/428.pdf diakses 16 April 2016

Motiwalla, L. F. (2007). Mobile Learning :

A Framework and evaluastion.

Computers \& Education, 49 (3), pp. 581-596.

http://dx.doi.org/10.1016/j.compedu. 2005.10.011

National Council of Teachers of Mathematics (NCTM). (2002). The Technology Principle: Principles and Standards for School Mathematics. Reston, VA: NCTM.

Nurhasnawati. (2011).

Media

Pembelajaran. Pekan Baru : Yayasan Pusaka Riau.

OECD. (2013). PISA 2012 Assessment and Analytical Framewrok:Matemathics, Reading, Science, Problem Solving and Financial Literacy, OECD Publishing.

http://dx.doi.org/10.1787/978926419 0511-en

Schwier, Richard and Misank, Earl R.(1993). "Multimedia Interactive Clean it Healthy". Jurnal Ilmiah Edutic. Vol.1, No.1, Nopember 2014 (http://journal.trunojoyo.ac.id/edutic/ article/view/396/370.pdf diakses pada12 April 2016)

Sanjaya, W. (2006). Strategi Pembelajaran Berorientasi Standar Proses
Pendidikan. Jakarta:Kencana Predana Media Group.

Supriatna, Dadang, dkk. (2009). "KONSEP DASAR DESAIN PEMBELAJARAN Bahan ajar untuk Diklat E-Training PPPPTK TK dan PLB”. PUSAT PENGEMBANGAN DAN PEMBERDAYAAN PENDIDIK DAN TENAGA KEPENDIDIKAN TAMAN KANAK - KANAK DANPENDIDIKANLUARBIASAht tp://jozhmunthe.yolasite.com/resourc es/3.Konsep_Dasar_Desain_Pembela jaran-www.tkplb.org.pdf diakses 04 Juni 2017

Tamimuddin, Muh. (2014). Pemanfaatan Mathematics Mobile Learning dalam Pembelajaran Matematika. PPPPTK MATEMATIKA YOGYAKARTA (http://fadjarp3g.files.wordpress.com /2008/06/8-makalah-tamimudinmobile learning.pdf diakses pada tanggal 3 Desember 2015)

Traxler, J. (2005). Defining Mobile Learning. In Proceeding of the IADIS International Conference : Mobile Learning 2005 (pp. 261266). Qawra, Malta : IADIS

Uno, Hamzah B. (2007). Model Pembelajaran : Menciptakan Proses Belajar Mengajar Yang Kreatif dan Efektif. Jakarta : PT. BumiAksara. 